\title{
Geochemical Characteristics and Geological Significance of the Tawangshan gold deposit in Dongfang City,Hainan Province
}

\author{
Ying XIONG ${ }^{a}$, Zi Qiang ZHU and Guang Yin LU \\ School of Geoscience and Info-Physics, Central South University, Changsha 410083, China
}

\begin{abstract}
TheTawangshan gold deposit is located in the southwest of the Gezhen ductile shear zone in southwestern Hainan Island. Major, trace and rare earth element characteristics of the least altered granites and altered granite ores, as well as the oxygen and hydrogen isotopic features of the quartz, the sulfur and lead isotopic features of the pyrites, galena from this deposit were systematically studied. The altered granite ores content of $\mathrm{Fe}_{2} \mathrm{O}_{3} /\left(\mathrm{Fe}_{2} \mathrm{O}_{3}+\mathrm{FeO}\right)$ ranges from 0.409 to 0.410 , showing strong magma reducibility. REE characteristics of the granite ores are similar to those of the least altered granites, indicating a close relationship between the mineralization and granite. Hydrogen and oxygen analysis results show that the content of 18OSMOW ranges from $7.7 \%$ to $16.3 \%$, $\delta{ }^{18} \mathrm{O}_{\mathrm{H}_{2} \mathrm{O}}$ ranges from $1.0 \%$ to $6.8 \%$, suggesting that the ore-forming fluid was the dual nature of the metamorphic and magmatic hydrothermal. The compositions of sulfur isotope and lead isotope imply that the metallogenic materials of the deposit derived from the deep magma mixing with the shell source material contamination. Ore deposit geological features reflect the obvious characteristics of magmatic hydrothermal and porphyritic granite is mineralized rocks, implying the deposit was formed in the post-collisional extensional tectonic setting.
\end{abstract}

\section{Introdution}

The Tawangshan gold deposit is located in the southeast of the Gezhen ductile shear zone, a small gold deposit newly discovered. After exploration, the deposit has submitted $1600 \mathrm{~kg}$ gold resources. However, due to lack of theoretical research on mining gold mineralization characteristics, mineralization and other systems, further prospecting mining has been caused a lot of constraints. Based on the field of exploration and geochemical analysis, the metallogenic regularity and the genesis of mine have been studied, in order to provide theoretical guidance to

Corresponding authors: Xiong ying, E-mail:32973457@qq.com further mining prospecting work, as well as enriching the theoretical knowledge Gezhen gold mineralization belt.

\section{Regional geological setting}

Tawangshan gold deposit is located in the western South China fold belt Wuzhishan fold system, Baisha depression belt and hold the plate crown area of the contact portion waterfront-Jinbo rift belt, south-eastern of Gezhen fault. The rock of the area is characterized by Kongliecun group, Tuolie group of Silurian System; Nanhao group, Qingxia group of Carboniferous System; E cha group of Permian System; Lu muwan group of Cretaceous System and Quaternary. Regional faults are 
well developed, there are Yalao fracture, Wangxia fracture, Yongwang fracture and Yan Woling fracture. The area magmatic is frequently activity, dominated by porphyritic biotite monzonite granite unit (porphyritic structure) $\rightarrow$ fine biotite monzonite granite (fine-grained granitic structure) $\rightarrow$ fine-grained biotite to life monzogranite unit (fine-grained granitic structure), composing of a sequence of structural evolution. The unit intruded into unit of Zhenghao and Permian E Cha group, and intruded by Bawangling super unit, Nam Young Ridge super intrusion. Zircon U-Pb isotopic age of the unit is $248 \pm 25 \mathrm{Ma}$, whole rock $\mathrm{Rb}-\mathrm{Sr}$ isochronal age is 245.9 4.2Ma (Wang,1991).

\section{Mining geology and mineralization characteristics}

\subsection{Geological characteristics}

The strata exposed area is mainly Quaternary stratigraphy, Late Palaeozoic Permian strata. Quaternary strata are mainly distributed in the wash, by the alluvial and alluvial gravel, clay, and loam composition. Permian strata exposed in the south and southeast of the area, with wide $100-800 \mathrm{~m}$, length of $4 \mathrm{~km}$, tending to the north-west, dipping $50-65^{\circ}$. The rock of Permian strata is characterized by crystalline limestone, microcrystalline biolistic limestone and metamorphic siliceous sandstone.

The structural fault is dominated by NNE - NEE trend. The NNE-trending faults which strike $10^{\circ}$, tend to the north-west, dip 70-80 ${ }^{\circ}$. This group faults cut through the Yanshanian biotite granite and Permian strata, with filling with broken quartz veins, lamprophyre vein and diorite vein. The NEE-trending group faults tend to northwest, $\operatorname{dip} 35^{\circ}-55^{\circ}$, followed by east-west fault was compressive echelon distribution, the local formation of gold-polymetallic ore body.

The area magmatism is frequently activity, dominated by Indosinian porphyritic granite and late Yanshanian biotite granite types. Indosinian porphyritic granite is explored in the north of the mining area, with a rock-like base. The late Yanshanian biotite granite is distributed in porphyritic granite batholith, with irregular rock stock. The west side of the rock strains of the long axis east to $1000 \mathrm{~m}$, minor $500 \mathrm{~m}$, and the eastern side semicircular rock strains, the major axis $700 \mathrm{~m}$, minor $500 \mathrm{~m}$.

\subsection{Mineralization characteristics}

According to the existing exploration project and expose fire assay analysis results, the Tawangshan gold deposit has delineated I , II ,III,IV gold ore belt. The gold ores are always distributed in east-west faults, with no obvious boundaries between gold and rock .Mostly vein ore bodies form as lenticular, lenticular, along with a complex branching and tends to strike, pinch out the reproduction, the expansion and contraction of the local formation of barren skylights and other characteristics.

I gold belt: with length of kilometres, width of meters to tens of meters, trending to east-west, this belt is composition of three ore bodies and two mineralized bodies, with lenticular shape. The gold ores has not been fully controlled, extending more than 200 meters.

II gold belt: with length of several hundred meters, width of a few meters to tens of meters, trending to east-west, this belt is a single ore body, composition of two ore bodies.

III gold belt: with length of kilometers, width of meters to tens of meters, trending to east- west.

IV gold belt: as the smallest alteration zones ,this belt were circled a gold orebody, with length of $50 \mathrm{~m}$, width of $3 \mathrm{~m}$, Au average grade of $1.2 \mathrm{~g} / \mathrm{t}$.

\section{Sample collection and analysis}

The study samples were collected from the deep drill core. Major elements, trace elements and REE samples are mainly collected from unaltered and altered granite (ore) sample, and $\mathrm{H}-\mathrm{O}$ isotope analysis samples are for the selection of the main mineralized quartz vein type ore of pure quartz minerals, but $\mathrm{S}-\mathrm{Pb}$ isotopes analysis samples are for $\mathrm{s}$ the altered granite ore, the selection of pure mineral pyrite, galena minerals as a single sample.

Major elements, trace elements and REE elements are anglicised in ALS Laboratory (analysis results in Table 1). H-O isotope analysis was finished in Wuhan Institute of Geology and Mineral Resources isotope geochemistry laboratory, with MAT261 Mass Spectrometer. Sulfur and lead isotopes are analysis in State Key Laboratory of Geological Processes and Mineral Resources measured at China University of Geosciences (Wuhan). 


\subsection{Granite of major, trace and REE characteristic}

\subsubsection{Major elements}

The content of $\mathrm{SiO}_{2}$ in unaltered granite ranges from 69.05 to $76.96 \mathrm{wt}$.\%.The total alkali content ranges from 7.75 to $9.40 \mathrm{wt} . \%$. The $\mathrm{Al}_{2} \mathrm{O}_{3}$ content ranges from 12.15 to 14.19 wt.\%. The $\mathrm{K}_{2} \mathrm{O}$ content is higher than the $\mathrm{Na}_{2} \mathrm{O}$ content. The rate of $\mathrm{K}_{2} \mathrm{O} / \mathrm{Na}_{2} \mathrm{O}$ ranges from 1.24 to 3.35, with a potassium-rich feature,belonging to high- $\mathrm{K}$ calc-alkaline series. The $\mathrm{MgO}, \mathrm{TiO}_{2}$ and $\mathrm{P}_{2} \mathrm{O}_{5}$ content ranges from 0.06 to $0.88 \mathrm{wt} . \%, 0.04$ to $0.43 \mathrm{wt} . \%, 0.015$ to $0.156 \mathrm{wt} . \%$.The characteristic of the altered granites is dominated by rich in $\mathrm{K}$, rich in alkali and poor in $\mathrm{SiO}_{2}$ content. The rate of $\mathrm{K}_{2} \mathrm{O} / \mathrm{Na}_{2} \mathrm{O}$ ranges from 1.02 to 1.66. The content of $\left(\mathrm{K}_{2} \mathrm{O}+\mathrm{Na}_{2} \mathrm{O}\right)$ ranges from 6.99 to 8.59wt.\%.The rate of $\mathrm{Fe}_{2} \mathrm{O}_{3} /\left(\mathrm{Fe}_{2} \mathrm{O}_{3}+\mathrm{FeO}\right)$ ranges from 0.409 to 0.410 , lower than China biotite granite average $(0.44)$ and the world granite average (0.47), suggesting that the magma has strong reduction.

\subsubsection{Ore-forming elements}

The altered granite is rich in $\mathrm{Au}, \mathrm{Ag}, \mathrm{Pb}, \mathrm{Zn}$. The content of $\mathrm{Pb}, \mathrm{Zn}$ and $\mathrm{Au}$ content was a significant positive correlation, suggesting that the gold mineralization is closely with lead-zinc mineralization. The $\mathrm{Cu}$ mineralization is not obvious. Either unaltered granites or altered granites ,the content of $\mathrm{W}, \mathrm{Mo}$, presently high-temperature ore-forming elements ,is very low, indicating that the mineralization temperature should be in medium-low temperature.

Table 1 Major, rare earth element and ore metal contents of the rocks and ores from the Tawangshan gold deposit

\begin{tabular}{|c|c|c|c|c|c|c|}
\hline \multirow{2}{*}{$\begin{array}{c}\text { Sample } \\
\text { name }\end{array}$} & \multicolumn{2}{|c|}{$\begin{array}{c}\text { unaltered } \\
\text { porphyritic }\end{array}$} & $\begin{array}{c}\text { unaltered biotite } \\
\text { granite }\end{array}$ & \multicolumn{2}{c|}{$\begin{array}{c}\text { altered } \\
\text { porphyritic }\end{array}$} \\
\cline { 2 - 8 } & $\begin{array}{c}\text { ZK34- } \\
\text { 3-H1 }\end{array}$ & $\begin{array}{c}\text { ZK34-3- } \\
\text { HK18-1- }\end{array}$ & $\begin{array}{c}\text { ZK18- } \\
\text { H1 }\end{array}$ & $\begin{array}{c}\text { ZK12-42 } \\
\text {-H6 }\end{array}$ & $\begin{array}{c}\text { ZK0-1- } \\
\text { H7 }\end{array}$ \\
\hline $\mathrm{SiO}_{2}$ & 76.96 & 69.05 & 72.56 & 74.42 & 57.96 & 51.23 \\
\hline $\mathrm{TiO}_{2}$ & 0.10 & 0.43 & 0.25 & 0.04 & 0.44 & 0.50 \\
\hline $\mathrm{Al}_{2} \mathrm{O}_{3}$ & 12.15 & 13.82 & 14.19 & 13.55 & 15.56 & 15.60 \\
\hline $\mathrm{Fe}_{2} \mathrm{O}_{3}$ & 0.17 & 1.16 & 0.81 & 0.39 & 1.36 & 1.54 \\
\hline $\mathrm{FeO}$ & 0.25 & 1.67 & 1.17 & 0.56 & 1.96 & 2.22 \\
\hline $\mathrm{MnO}$ & 0.01 & 0.06 & 0.04 & 0.04 & 0.09 & 0.09 \\
\hline $\mathrm{MgO}$ & 0.06 & 0.88 & 0.58 & 0.09 & 1.48 & 1.66 \\
\hline $\mathrm{CaO}$ & 0.01 & 1.47 & 1.90 & 0.31 & 3.55 & 3.63 \\
\hline $\mathrm{Na}_{2} \mathrm{O}$ & 2.16 & 2.89 & 3.55 & 3.33 & 3.27 & 3.52 \\
\hline
\end{tabular}

\begin{tabular}{|c|c|c|c|c|c|c|}
\hline $\mathrm{K}_{2} \mathrm{O}$ & 7.24 & 4.86 & 4.43 & 5.63 & 3.72 & 3.61 \\
\hline $\mathrm{P}_{2} \mathrm{O}_{5}$ & 0.015 & 0.156 & 0.063 & 0.021 & 0.146 & 0.169 \\
\hline $\mathrm{Total}$ & 99.13 & 96.45 & 99.54 & 98.38 & 89.54 & 83.77 \\
\hline $\mathrm{Rb}$ & 367 & 218 & 178 & 194 & 397 & 335 \\
\hline $\mathrm{Nb}$ & 11 & 11 & 8 & 9 & 18 & 16 \\
\hline $\mathrm{La}$ & 39.5 & 44.8 & 27.9 & 29 & 78.4 & 36.8 \\
\hline $\mathrm{Ce}$ & 85.8 & 84 & 53.8 & 53.9 & 149.5 & 69.2 \\
\hline $\mathrm{Pr}$ & 8.95 & 9.18 & 5.79 & 5.87 & 15.35 & 7.24 \\
\hline $\mathrm{Nd}$ & 31.4 & 31.2 & 21.4 & 21.6 & 52 & 25.5 \\
\hline $\mathrm{Sm}$ & 6.21 & 5.55 & 3.91 & 3.83 & 8.82 & 4.48 \\
\hline $\mathrm{Eu}$ & 0.44 & 0.93 & 0.93 & 0.79 & 1.38 & 0.88 \\
\hline $\mathrm{Gd}$ & 5.28 & 4.12 & 2.55 & 2.41 & 6.56 & 2.71 \\
\hline $\mathrm{Tb}$ & 1.13 & 0.56 & 0.34 & 0.33 & 0.93 & 0.4 \\
\hline $\mathrm{Dy}$ & 7.19 & 2.76 & 1.87 & 1.93 & 5.26 & 2.21 \\
\hline $\mathrm{Ho}$ & 1.52 & 0.48 & 0.35 & 0.33 & 0.94 & 0.43 \\
\hline $\mathrm{Er}$ & 4.69 & 1.23 & 1.11 & 1 & 2.57 & 1.19 \\
\hline $\mathrm{Tm}$ & 0.71 & 0.17 & 0.15 & 0.16 & 0.4 & 0.18 \\
\hline $\mathrm{Yb}$ & 4.67 & 0.99 & 1 & 1.18 & 2.6 & 1.05 \\
\hline $\mathrm{Lu}$ & 0.72 & 0.15 & 0.16 & 0.18 & 0.4 & 0.17 \\
\hline $\mathrm{Y}$ & 37 & 13 & 9.9 & 10.4 & 29.3 & 11.3 \\
\hline $\mathrm{RREE}$ & 198.21 & 186.12 & 121.26 & 122.51 & 325.11 & 152.44 \\
\hline $\mathrm{LREE}$ & 172.3 & 175.66 & 113.73 & 114.99 & 305.45 & 144.1 \\
\hline $\mathrm{HREE}$ & 25.91 & 10.46 & 7.53 & 7.52 & 19.66 & 8.34 \\
\hline $\mathrm{LREE} / \mathrm{HREE}$ & 6.65 & 16.79 & 15.1 & 15.29 & 15.54 & 17.28 \\
\hline $\mathrm{LaN} / \mathrm{SmN}$ & 4.11 & 5.21 & 4.61 & 4.89 & 5.74 & 5.3 \\
\hline $\mathrm{GdN} / \mathrm{YbN}$ & 0.94 & 3.44 & 2.11 & 1.69 & 2.09 & 2.14 \\
\hline$\delta \mathrm{Eu}$ & 0.23 & 0.57 & 0.84 & 0.74 & 0.53 & 0.71 \\
\hline$\delta \mathrm{Ce}$ & 1.07 & 0.96 & 0.98 & 0.96 & 0.99 & 0.98 \\
\hline $\mathrm{Au}$ & 14 & 14 & 15 & 19 & 205 & 29 \\
\hline $\mathrm{Ag}$ & 449 & 150 & 1971 & 1989 & 448 & 1049 \\
\hline $\mathrm{Cu}$ & 11 & 6 & 16 & 22 & 15 & 1 \\
\hline $\mathrm{Pb}$ & 57 & 57 & 77 & 54 & 133 & 45 \\
\hline $\mathrm{Zn}$ & 59 & 81 & 103 & 77 & 84 & 45 \\
\hline $\mathrm{Mo}$ & 2 & 1 & 19 & 1 & 1 & 0 \\
\hline $\mathrm{W}$ & 6 & 0 & 1 & 0 & 0 & 0 \\
\hline & & & & & & \\
\hline
\end{tabular}

\subsubsection{REE elements}

The content of rare earth elements in unaltered granite ranges from $121.26 \times 10^{-6}$ to $198.21 \times 10^{-6}$, distribution patterns rightist, LREE enrichment (Fig. 1a). The rate of LREE/HREE ranges from 6.65 to 16.79. The rate of $(\mathrm{La} / \mathrm{Yb}) \mathrm{N}$ ranges from 6.07 to 32.46 . The rate of $(\mathrm{Gd} / \mathrm{Yb}) \mathrm{N}$ ranges from 0.94 to 3.44.The rate of $(\mathrm{La} / \mathrm{Sm})$ $\mathrm{N}$ ranges from 4.11 to 5.21 . The $\delta$ Eu content ranges from 0.23 to 0.84 . The $\delta \mathrm{Ce}$ content ranges from 0.96 to 1.07 .

The content of rare earth elements in altered granite ranges from $126.85 \times 10^{-6}$ to $325.11 \times 10^{-6}$, distribution patterns rightist, LREE enrichment (Fig. 1b). The rate of 
LREE / HREE ranges from 15.54 to 19.83. The rate of $(\mathrm{La} / \mathrm{Yb}) \mathrm{N}$ ranges from 21.63 to 25.22 . The rate of $(\mathrm{Gd} /$ $\mathrm{Yb}) \mathrm{N}$ ranges from 1.94 to 2.21 .The rate of $(\mathrm{La} / \mathrm{Sm}) \mathrm{N}$ ranges from 5.30 to 6.62 .The $\delta \mathrm{Eu}$ content ranges from 0.53 to 0.72 . The $\delta \mathrm{Ce}$ content ranges from 0.96 to 0.99 .
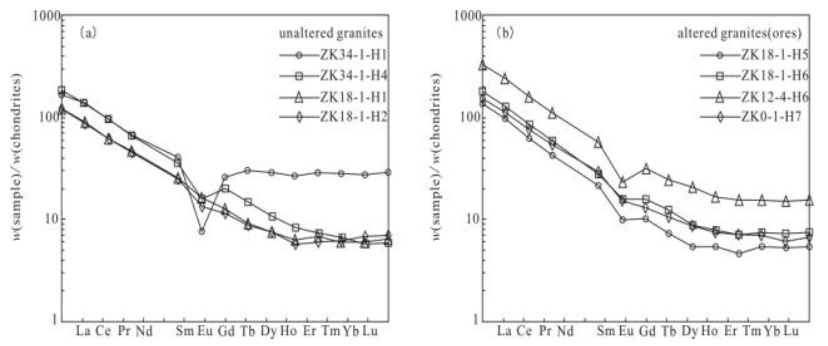

Fig.1 Chondrite normalized REE patterns of the granites

\subsection{Isotopic Characteristics}

\subsection{1 $\mathrm{H}-\mathrm{O}$ isotope}

The hydrogen and oxygen isotopic date of the Tawangshan gold deposit are listed in Table 2. Theס D of all samples range from $-59.0 \% 0-99.0 \%$,showing significant isotopic fractionation occurrence. The $\delta$ ${ }^{18} \mathrm{O}_{\text {SMOW }}$ of all samples range from $7.7 \% 0 \sim 16.3 \%$. The $\delta$ ${ }^{18} \mathrm{O}_{\mathrm{H} 2 \mathrm{O}}$ of all samples range from $1.0 \% \sim 6.8 \%$, with an average of $4.1 \%$ 。

Table 2 Oxygen and hydrogen isotopic date of the Tawangshan gold deposit

\begin{tabular}{|c|c|c|c|c|c|}
\hline $\begin{array}{c}\text { sample } \\
\text { number }\end{array}$ & types ore & $\begin{array}{c}\delta^{18} \mathrm{O}_{\text {SMOw }} / \\
\% 0\end{array}$ & $\begin{array}{c}\delta \mathrm{D}_{\text {SMOw }} \\
/ \% 0\end{array}$ & $\begin{array}{c}\text { homogeniz } \\
\text { ation } \\
\text { temp/ } /{ }^{\circ} \mathrm{C}\end{array}$ & $\begin{array}{c}\delta \mathrm{O}_{\mathrm{H} 2 \mathrm{O}} / \\
\% 0\end{array}$ \\
\hline Ta-7 & $\begin{array}{c}\text { alterd rock type } \\
\text { gold ore }\end{array}$ & 9.5 & -96 & 289 & 2.2 \\
\hline Ta-8 & $\begin{array}{c}\text { alterd rock type } \\
\text { gold ore }\end{array}$ & 10.6 & -75.8 & 306 & 3.9 \\
\hline Ta-9 & $\begin{array}{c}\text { alterd rock type } \\
\text { gold ore }\end{array}$ & 10.4 & -87.1 & 296 & 3.3 \\
\hline Ta-10 & $\begin{array}{c}\text { alterd rock type } \\
\text { gold ore }\end{array}$ & 7.7 & -59 & 357 & 2.6 \\
\hline Ta-11 & $\begin{array}{c}\text { alterd rock type } \\
\text { gold ore }\end{array}$ & 12.4 & -99 & 315 & 6.0 \\
\hline Ta-12 & $\begin{array}{c}\text { alterd rock type } \\
\text { gold ore }\end{array}$ & 12.9 & -91 & 283 & 5.3 \\
\hline Ta-13 & $\begin{array}{c}\text { quartz vein type } \\
\text { gold ore }\end{array}$ & 16.4 & -64.3 & 240 & 6.8 \\
\hline Ta-14 & $\begin{array}{c}\text { quartz vein type } \\
\text { gold ore }\end{array}$ & 11.6 & -77 & 219 & 1.0 \\
\hline Ta-15 & $\begin{array}{c}\text { quartz vein type } \\
\text { gold ore }\end{array}$ & 16.3 & -70.1 & 240 & 6.7 \\
\hline Ta-16 & $\begin{array}{c}\text { quartz vein type } \\
\text { gold ore }\end{array}$ & 14.3 & -59 & 219 & 3.6 \\
\hline
\end{tabular}

\subsubsection{S isotope}

The sulfur isotope of pyrite, galena values are listed in Table 3.The $\delta^{34} \mathrm{~S}$ of all sample range from $6.3 \%$ to $9.1 \%$, with an average of $7.8 \%$ and range of $2.8 \%$. Sulfur isotope variation range is narrow, relatively homogeneous composition and exhibiting a relatively enriched in ${ }^{34} \mathrm{~S}$ isotope characteristics.

Table 3 Sulfur isotope results from the Tawangshan gold deposit

\begin{tabular}{|c|c|c|c|}
\hline sample number & types ore & sulfide & $\delta^{34} \mathrm{~S} / \%$ o \\
\hline Ta-7 & alterd rock type gold ore & pyrite & 7.8 \\
\hline Ta-8 & alterd rock type gold ore & pyrite & 8.0 \\
\hline Ta-9 & alterd rock type gold ore & pyrite & 8.0 \\
\hline Ta-10 & alterd rock type gold ore & pyrite & 7.6 \\
\hline Ta-11 & alterd rock type gold ore & pyrite & 7.6 \\
\hline Ta-12 & alterd rock type gold ore & galena & 6.3 \\
\hline Ta-13 & quartz vein type gold ore & galena & 7.1 \\
\hline Ta-14 & quartz vein type gold ore & galena & 8.2 \\
\hline Ta-15 & quartz vein type gold ore & pyrite & 8.6 \\
\hline Ta-16 & quartz vein type gold ore & pyrite & 9.1 \\
\hline
\end{tabular}

\subsection{3 $\mathrm{Pb}$ isotope}

The lead isotope of galena values are listed in Table 4.The rate of ${ }^{206} \mathrm{~Pb} /{ }^{204} \mathrm{~Pb}$ ranges from 18.09 to 18.39 , with an average of 18.25 . The rate of ${ }^{207} \mathrm{~Pb} /{ }^{204} \mathrm{~Pb}$ ranges from 15.47 to 15.58 , with an average of 15.53. The rate of ${ }^{208} \mathrm{~Pb} /{ }^{204} \mathrm{~Pb}$ ranges from 37.74 to 38.17 , with an average of 37.91.The content of $\mu$ ranges from 9.24 to 9.43 , with an average of 9.34. The content of $\omega$ ranges from 34.18 to 35.35 , with an average of 34.56 .

Table 4 Lead isotope results from the Tawangshan gold deposit

\begin{tabular}{|c|c|c|c|c|c|c|c|}
\hline $\begin{array}{c}\text { sample } \\
\text { number }\end{array}$ & $\begin{array}{c}{ }^{206} \mathrm{~Pb} \\
{ }^{204} \mathrm{~Pb}\end{array}$ & $\begin{array}{c}{ }^{207} \mathrm{~Pb} \\
{ }^{204} \mathrm{~Pb}\end{array}$ & $\begin{array}{c}{ }^{208} \mathrm{~Pb} \\
{ }^{204} \mathrm{~Pb}\end{array}$ & $\mu$ & $\omega$ & $\triangle \beta$ & $\Delta \gamma$ \\
\hline $\mathrm{Ta}-7$ & 18.29 & 15.54 & 37.88 & 9.36 & 34.33 & 14.10 & 17.77 \\
\hline Ta-8 & 18.21 & 15.49 & 37.85 & 9.27 & 34.18 & 10.84 & 16.96 \\
\hline Ta-9 & 18.34 & 15.56 & 38.01 & 9.39 & 34.78 & 15.40 & 21.26 \\
\hline Ta-10 & 18.18 & 15.52 & 37.83 & 9.33 & 34.52 & 12.79 & 16.43 \\
\hline Ta-11 & 18.39 & 15.58 & 38.17 & 9.43 & 35.35 & 16.71 & 25.56 \\
\hline Ta-12 & 18.09 & 15.47 & 37.74 & 9.24 & 34.18 & 9.53 & 14.01 \\
\hline
\end{tabular}




\section{Discussion}

\subsection{Ore-forming fluid source}

Projecting the isotope date (Table 2) onto hydrogen and oxygen isotopic composition diagram (Fig.2), showing that the almost sample of isotope date are fallen on the area near the magmatic water, and some sample is fallen metamorphic water area. This phenomenon indicates that ore-forming fluids have reaction with metamorphic rocks as it flowing from deep. As well as, the rain hydrothermal may be fallen in mineralization process, and may be very favourable. Therefore, the ore-forming fluid of the Tawangshan gold deposit has a characteristic with metamorphic and magmatic hydrothermal as a mixed fluid characteristic.

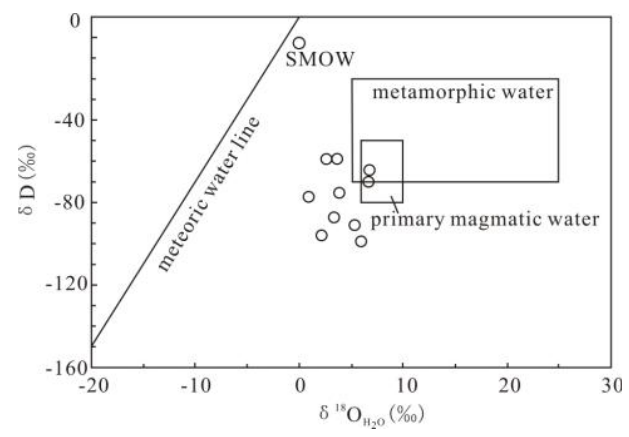

Fig.2 Plot of hydrogen and oxygen isotopes for gold ores of the Tawangshan gold deposit

\subsection{Forming material source}

\subsubsection{S isotope tracer}

Compared to sulfur isotope reservoir (Ohmoto and Rye, 1979) (Fig. 3), the content of sulfur isotope in Tawangshan gold deposit is more than the content of sulfur isotope in magmatic sulfur $\left(\delta^{34} \mathrm{~S}=0 \pm 5 \%\right.$ ), while lower than the content in seawater $\left(\delta^{34} \mathrm{~S}\right.$ in Cambrian seawater limited of $15 \%$ ). Meanwhile, the value of $\delta^{34} \mathrm{~S}$ shows a high positive value, closely to oxidizing granitites (Coleman, 1979) .It may be associated with fluid degassing. Thus we believe that the sulfur isotope in Tawangshan gold deposit is from magma sulfur mixing with the portion of the stratum sulfur.

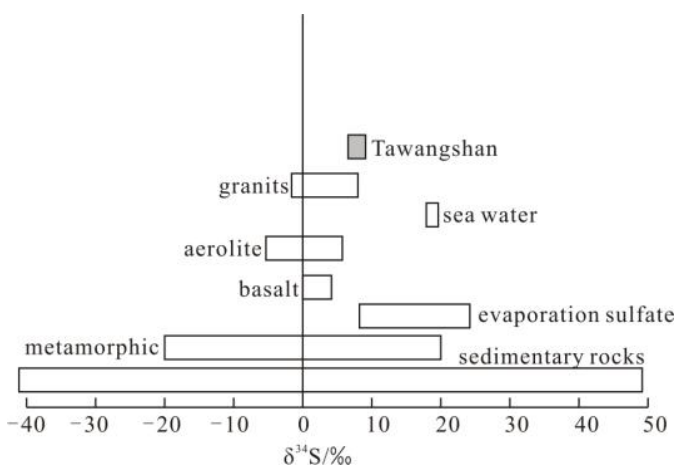

Fig.3 Sulfur isotope histograms for gold ores of the

Tawangshan gold deposit

\subsection{2 $\mathrm{Pb}$ isotope tracer}

Project the lead isotope values of the Tawangshan gold deposit on the lead isotope evolution of tectonic setting diagram(Zartman,1981). In ${ }^{207} \mathrm{~Pb} /{ }^{204} \mathrm{~Pb}-{ }^{206} \mathrm{~Pb} /{ }^{204} \mathrm{~Pb}$ diagram (Fig.4a), the sample is located between the mantle and the orogenic belt. In ${ }^{208} \mathrm{~Pb} /{ }^{204} \mathrm{~Pb}-{ }^{206} \mathrm{~Pb} /{ }^{204} \mathrm{~Pb}$ diagram (Fig.4b), the sample is located between the orogenic belt and upper crust, reflecting that the lead is from the deep source material related to orogeny. IN the $\triangle \beta-\triangle \gamma$ diagram(Fig.5), the sample is located in the mantle and mixed upper crust and mantle-derived lead (closer to the magmatism).So we can think that the lead of the Tawangshan gold deposit is from deep mantle source, mixing some crust lead source.
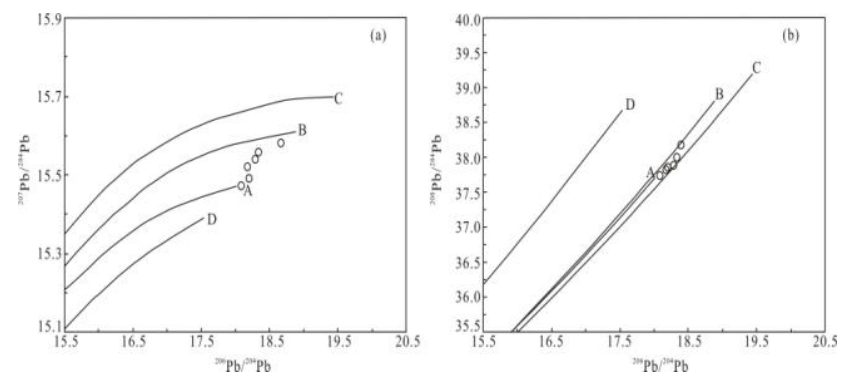

Fig.4 Diagram showing evolutionary tectonic setting of $\mathrm{Pb}$ isotope from the Tawangshan gold deposit

A-mantle; B- orogenic belt; C- upper crust; D- lower crust

\subsection{Metallogenic tectonic setting}

Generally, the ore-forming hydrothermal which the deposit related with granitites is from the richment of volatile components late of granitic evolution. And then the granitic magnatism should be earlier than the mineralization events. Therefore, granitic magmatism tectonic environment can reflects tectonic setting of 
mineralization. Projected the trace elements onto the tectonic discrimination diagram (Fig.7), the sample are mainly fallen in syn-collision granites area. The syn-collision granites include continent - continent collision and late the collision and continue to converge on the role (Han, 2007). Studies have shown that the collision organic belt magmatic hydrothermal deposits are formed in the collision extensional tectonic environment, not in the main stage of collision environment (Kerrich et al, 2000; Hou et al, 2011).This is consistent with Indosinian gold mineralization tectonic environment within Gezhen fault belt, which is in extensional tectonic environment in Indosinian(Ding and Peng,1993). Therefore, the tectonic environment of the Tawangshan gold deposit may be extensional tectonic environment after the collision.

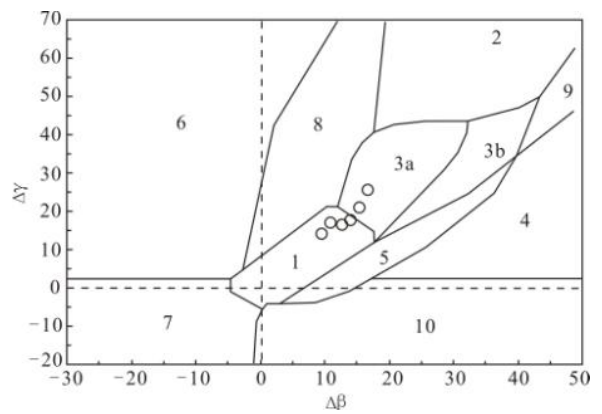

Fig.5 $\Delta \beta-\Delta \gamma$ diagram of genetic classification of ore lead isotopes from Tawangshan gold deposit

1-mantle-derived lead;2-upper crust -derived lead;3-mixed upper crust and mantle-derived lead ( 3a.magmatism ; 3b.sedimentation); 4-lead from chemical deposition; 5-lead from submarine hydrothermalism; 6-lead from medium-deep matamorphism ; 7-lower crust-derived lead from matamorphism; 8-lead from orogenic belt; 9-lead from upper crust of ancient shale; 10-lead from retrogrande metamorphism
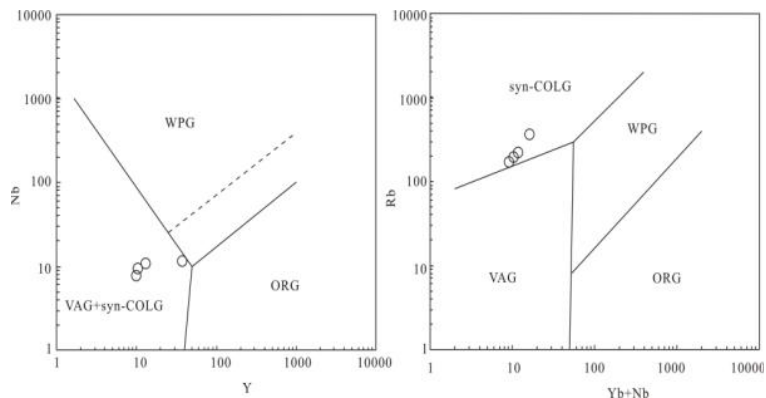

Fig.6 Diagrams of tectonic environment for granites of Tawangshan gold deposit

VAG-volcanic arc granites; ORG-oceanic ridge granites; WPG-within plate granites; syn-COLG-syn-collision granites

\section{Conclusions}

The ore body is mainly quartz veins type and altered rock type in the Tawangshan gold deposit, hosting in granite. The granite is rich in medium -low temperature ore-forming elements. The REE characteristics of REE in altered granite (ores) is similarly with the unaltered granite, showing the closely relation between mineralization with granite.

The ore-forming fluids is from magmatic hydrothermal and metamorphic hydrothermal, according to the H-O isotopic characteristics. The source of ore-forming elements is from deep magma, mixing with crust lead, based on the $\mathrm{S}, \mathrm{Pb}$ isotopic characteristics.

The Tawangshan gold deposit is a magmatic hydrothermal deposits, formed after the collision extensional environment.

\section{References}

1 Li Xianhua, Zhou Hanwen, Ding Shijiang.Ocean ridge in metamorphic rocks of Hainan: ocean crust relic of Gut Tis?[J]. Chinese science bulletin, 45,1(2004).

2 Li Zhengxiang,LI Xianhua.Formation of the 1300 $\mathrm{km}$-wide intracontinental orogen and postorogenic magmatic province in Mesozoic South China:A flat-slab subduction model[J].Geology,,35,2(2007).

3 Kerrich R, Goldfarb R, Garwin S. The characteristics, origins,and geodynamic settings of supergiant gold metallogenic provinces[J]. Science in China Series D: Earth Science, 43,1(2004).

4 Ohmoto H. Stable isotope geochemistry of ore deposits[J].Reviews in Mineralogy and Geochemistry,16,1(1986).

5 Wu Chuanjun, Xu Deru, Fu Yangrong. Research of metallogenic regularity and metallogenic mechanism of important types of gold deposits in Hainan island[J].Acta Mineralogica Sinica, 32,S1(2011).

6 Xia Bin,Cui Xuejun, Zhang Yanhua. Dynamic factors for the opening of south china sea and a numerical modeling discussion[J].Geotectonica et Metallogenia, 29,2(2005). 